\title{
Economic analysis of a pragmatic randomised trial of home visits by a nurse to elderly people with hypertension in Mexico
}

\author{
Carmen García-Peña, MD, MSC, PhD, (1) Margaret Thorogood, PhD, ${ }^{(2)}$ D avid W onderling, Ba, MSc, ${ }^{(3)}$ \\ Sandra Reyes-Frausto, MD, MsC, PhD. (4)
}

\section{García-Peña C,Thorogood M, Wonderling D, Reyes-Frausto S. Economic analysis of a pragmatic randomised trial of home visits by a nurse to elderly people with hypertension in Mexico. Salud Publica Mex 2002;44:14-20. \\ The English version of this paper} is available at: http://www.insp.mx/salud/index.htm

\begin{abstract}
Objective. To analyse the costs and the effectiveness of an inter vention of home visits made by nurses to elderly people ver sus usual care given by the family medicine units. $\mathbf{M a}$ terial and Methods. A sample of 4777 subjects aged 60 years and over covered by the Mexican Institute of Social Security (Instituto Mexicano del Seguro Social, IMSS) were screened. Those with a systolic and/or diastolic blood pressure level higher or equal than $160 / 90 \mathrm{~mm} \mathrm{H}$ g were randomly allocated to the intervention or control groups. The inter vention consisted of visits at home by nurses who gave health and lifestyle advice to the participants. The economic evaluation was considered from a health services and patient perspective. Direct and indirect costs were calculated as incremental. Effectiveness was measured in terms of cost per millimetre of mercury reduced. Results. Three hundred and forty five participants were allocated to the inter vention group and compared with 338 controls. At the end of the intervention period the difference in the mean change in systolic blood pressure was $3.31 \mathrm{~mm} \mathrm{Hg}(95 \% \mathrm{Cl} 6.32,0.29 ; p=0.03)$ comparing with the control group. In diastolic blood pressure the difference was $3.67(95 \% \mathrm{Cl} 5.22,2.12 ; \mathrm{p}<0.001)$. The total cost of the intervention was 101901.66 pesos. The in-
\end{abstract}

\author{
García-Peña C,Thorogood M, \\ Wonderling D, Reyes-Frausto S. \\ Análisis económico de un ensayo clínico aleatorizado \\ de visitas de enfermera en casa a ancianos \\ con hipertensión en México. \\ Salud Publica Mex 2002;44:14-20. \\ El texto completo en inglés de este artículo está \\ disponible en: http://www.insp.mx/salud/index.html
}

\section{Resumen}

Objetivo. Analizar los costos y la efectividad de una intervención basada en visitas de enfermería en casa a ancianos hipertensos comparada con el tratamiento usual otorgado por el médico familiar. Material y métodos Una muestra de 4777 sujetos de 60 años y más derechohabientes del Instituto Mexicano del Seguro Social (IMSS) fueron sometidos a escrutinio. Aquellos con cifras sistólica o diastólica iguales o superiores a 160/90 mm Hg fueron asignados aleatoriamente al grupo de intervención 0 al control. La intervención consistió en visitas de enfermera en casa que daban promoción de la salud. La evaluación económica fue considerada desde una perspectiva del paciente y de los servicios de salud. Costos directos e indirectos fueron considerados como incrementales. La efectividad fue medida en términos de costo por $\mathrm{mmH} g$ reducido. Resultados Trescientos cuarenta y cinco participantes fueron aleatorizados al grupo de intervención y comparados con 338 controles. Al final del periodo de intervención la diferencia en el cambio promedio en presión arterial sistólica fue de $3.31 \mathrm{~mm} \mathrm{Hg}$ (IC 95\% 6.32, $0.29 ; p=0.03$ ) comparado con el grupo control. La diferencia en presión arterial diastólica fue de $3.67 \mathrm{~mm} \mathrm{Hg}$ (IC 95\% $5.22,2.12 ; p<0.001)$. El costo total de la intervención fue de

This trial was funded by the $\mathrm{N}$ ational Council of Science and Technology, Mexico (Conacyt) and the Mexican Institute of Social Security (IMSS).

(1) Area de Investigación en Servicios de Salud. Instituto Mexicano del Seguro Social. México, D.F., México.

(2) Health Promotion Research Unit. London School of Hygiene and Tropical Medicine.

(3) Cancer and Public Health Unit. London School of Hygiene and Tropical Medicine.

(4) Department of Epidemiology and Public Health. University of Leicester, United Kingdom.

Received on: January 1,2001 • Acepted on: 0 ctober 3, 2001

Address reprint requests to: D ra. Ma. del Carmen García-Peña. D ivisión de Investigación Epidemiológica y en Servicios de Salud, Edificio Bloque "B", Cuarto piso, Unidad de Congresos, Centro Médico N acional Siglo XXI.Av. Cuauhtémoc 330, colonia D octores. 06125 México, D.F., México. E-mail: mcgp1@ terra.com.mx 
tervention cost per patient was 34.61 pesos (US $\$ 3.78),(\mathrm{Cl}$ $95 \% 34.44,35.46)$. The cost-effectiveness ratios was 10.46 pesos (US\$1.14) for systolic (CI 95\% 129.31,5.51) and 9.43 (US\$1.03) for diastolic (CI 95\% 19.90, 2.49). Conclusions The reduction in blood pressure obtained may well justify the small incremental cost of the intervention. The English version of this paper is available too at: http://www.insp.mx/ salud/index.htm

Key words: hypertension; elderly po pulation; cost effectiveness; Mexico
101,901.66 pesos. El costo por paciente fue de 34.61 pesos (US\$3.78), (IC 95\% 34.44, 35.46). La razón de costo efectividad fue de 10.46 pesos (US\$1.14) para presión sistólica (IC $95 \% 129.31,5.51$ ) y 9.43 (US\$1.03) para presión diastólica (IC 95\% 19.90, 2.49). Conclusiones. La reducción de la presión arterial parece valer el costo incremental de la intervención. El texto completo en inglés de este artículo también está disponible en: http://www.insp.mx/salud/index.html

Palabras clave: hipertensión; población anciana; costoefectividad; México
$\mathrm{T}$ he ageing population and the concomitant increasing prevalence of non-communicable diseases is an important issue in the health agenda of Mexico. ${ }^{1,2}$ Different ways of providing health care for the elderly are being studied to identify the most effective policies. A pragmatic randomised trial of home visits made by nurses to elderly people with hypertension in Mexico has reported the effectiveness of this intervention in reducing blood pressure levels at six months. ${ }^{3,4}$ There was a significant reduction in blood pressure, as well as an increased proportion of participants undertaking regular brisk walking. There was also a significant increase in the proportion of participants on hypotensive medication. However, there was no difference in weight reduction or salt excretion between the intervention and control group. Financial resources for health are inevitably limited and there are many competing demands. It is therefore important to determine the cost-effectivenss of a policy before recommending that it be incorporated in health care provided by the Mexican Institute of Social Security (Instituto Mexicano del Seguro Social (IMSS). A number of studies have evaluated the cost and effects of antihypertensive drugs, ${ }^{5-8}$ but far fewer have evaluated health promotion strategies for reducing hypertension, and even fewer have considered the effect in old people. Health checks to reduce cardiovascular risk factors in the general population ${ }^{9,10}$ have been shown to be cost-effective although, this depends on the duration of the effect.

This report estimates the incremental costs and effects of home visits made by nurses to elderly people in comparison with the usual care provided by the family medicine units.

\section{Material and Methods}

The design of the trial, methods and main findings have been reported previously.,4 Briefly, 4777 participants aged 60 years and over were screened. Those previously known as hypertensives or those with new diagnosis who had a systolic and/or diastolic blood pressure level higher or equal to $160 / 90 \mathrm{~mm} \mathrm{Hg}$ respectively, were randomly allocated to the intervention or control arm. The intervention consisted of visits at home at least fortnightly by nurses during a six month period. The nurses were first given training about ageing, clinical aspects of hypertension, personal interviews, health behaviour change models, process of negotiation and ethical aspects of home visits. During visits, the nurse measured blood pressure and the nurse and patient reviewed information from the baseline health check, and discussed possible lifestyle changes. The nurse tried to guide their patients to a healthier lifestyle and suggested different alternative ways to achieve the changes and negotiated specific targets. The nurse also reviewed the pharmacological treatment and compliance was encouraged. The patient led the process of negotiation, while the nurse provided information about risks and benefits from lifestyle change. Both groups continued to receive the usual care provided by the family physicians. The trial did not interfere with the care given by the doctors at the family medicine units. A different team of nurses measured blood pressure and weighed the participants at baseline and at final follow-up. They also collected a sample of urine for calculating sodium excretion and administered a questionnaire to ascertain the presence of risk factors, use of medication and self-reported level of physical activity. There were 364 participants randomised to the intervention group and 354 to the control group. The 19 participants in the intervention group and 16 in the control group dropped out before the final evaluation. The flow of the subjects through the study is presented in Figure 1. Baseline characteristics of the participants are included in Table I.

\section{Costs}

The evaluation was considered from a health services and patient perspective. All costs are reported in 1998 Mexican pesos and US dollars. Costs were not discount- 
ed since the time period of the intervention was six months, apart from the cost of the sphygmomanometers, which was discounted assuming a capital life expectancy of five years and a discount rate of $6 \%$. Costs which related to the process of research rather than the provision of the intervention were excluded. All the costs of the intervention were considered to be incremental to the cost of existing care since the family medicine units do not have an existing programme. Nurse time was recorded during the trial, including the duration of each visit, the time spent travelling, and time spent on general issues such as planning, $\mathrm{co}^{-}$ difying and reporting. The cost of transport was also included. Using this information, an average cost of a visit was calculated, which is the cost of nurse time during the consultation plus time spent travelling. The unit costs of the time of the nurses and their instructors were calculated from their salaries (17.50 pesos per hour for the nurses). Supplies and stationery costs were collected from institutional records. Equipment costs (sphygmomanometers and stethoscopes) were collected from the institutional distributor. Clinic/office space was costed using the daily accounting cost of a room at IMSS. The impact of the intervention on the number of family physicians consultations was measured. Patient costs were investigated.

A cost for each patient was calculated by multiplying the number of visits that individual had received by the average cost of a visit plus the average of the other costs (equipment, office space, training, supplies). A confidence interval for mean cost, as well as mean effect, was calculated using the $\mathrm{t}$-distribution with the variation in cost being attributable to the variation in the number of visits received. Similarly the difference in costs, or difference in effects was also calculated.

Cost/effectiveness was measured in terms of cost per millimetre of mercury reduced. Confidence intervals for the cost-effectiveness ratios were estimated using Fieller's method, which takes account of the skewness of the distribution of the ratio. ${ }^{11}$

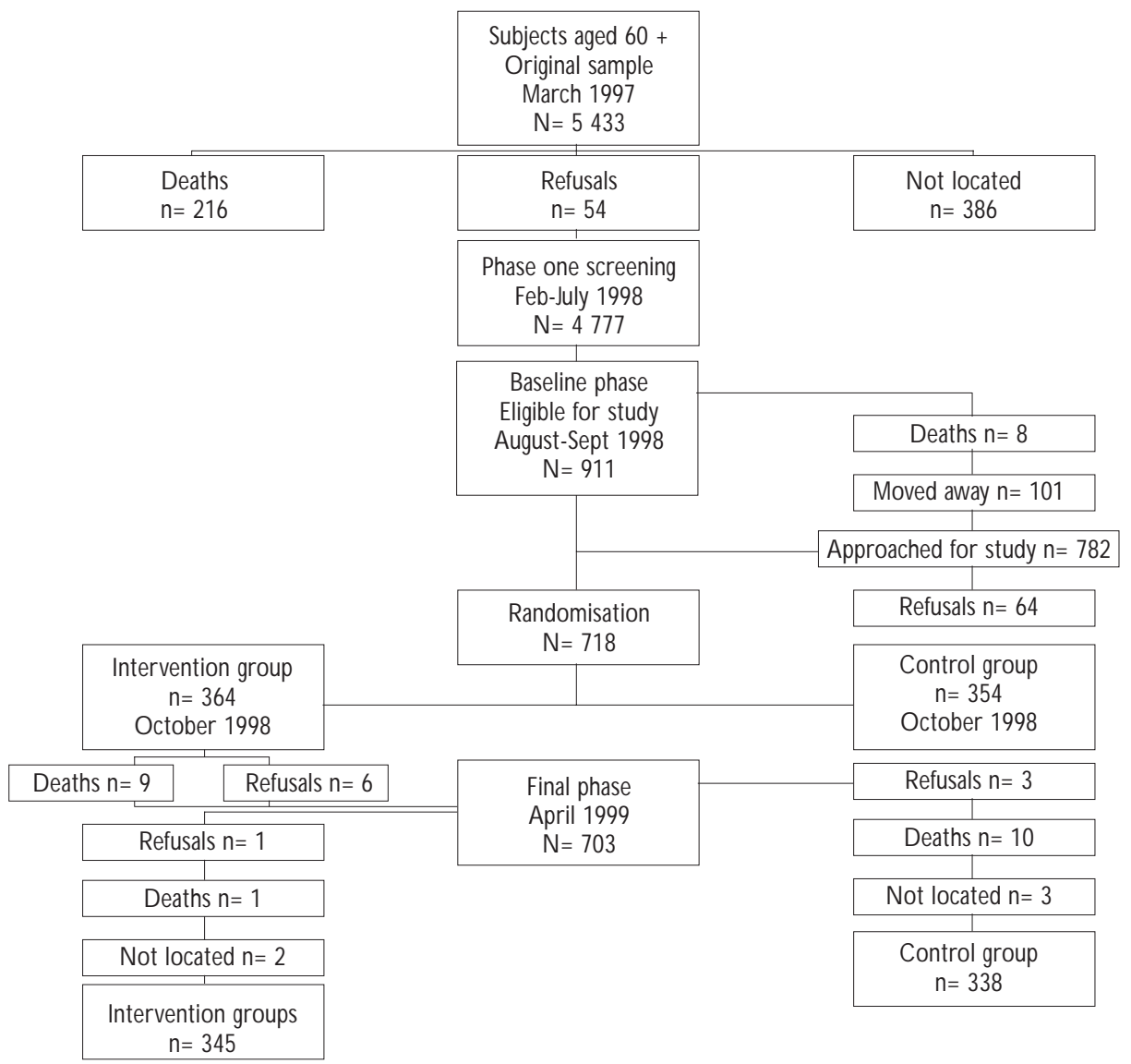

Figure 1. Flow of subjects through the study. Mexican Institute of Social Security (Instituto Mexicano del Seguro Social), 1998 
Table 1

\section{Baseline Characteristics of Intervention and Control Groups. Mexican Institute of Social Security (Instituto Mexicano del Seguro Social), 1998}

\begin{tabular}{|c|c|c|}
\hline & $\begin{array}{l}\text { Control } \\
n=354\end{array}$ & $\begin{array}{c}\text { Intervention } \\
n=364\end{array}$ \\
\hline Mean age in years (SD) & $70.34(6.92)$ & $70.8(7.11)$ \\
\hline Female, $\%$ & 65.0 & 62.9 \\
\hline \multicolumn{3}{|l|}{ Education level, \% } \\
\hline Primary & 57.6 & 55.0 \\
\hline Secondary & 13.6 & 12.1 \\
\hline High school and more & 3.4 & 5.5 \\
\hline Single, widowed or divorced, \% & 36.1 & 40.6 \\
\hline Lives alone, $\%$ & 15.5 & 8.2 \\
\hline \multicolumn{3}{|l|}{ Income/month*, \% } \\
\hline$\$ 10-\$ 109$ & 55.6 & 56.6 \\
\hline$\$ 110-\$ 209$ & 21.5 & 26.1 \\
\hline$\$ 210$ and more & 4.0 & 3.8 \\
\hline No own income & 18.9 & 13.5 \\
\hline \multicolumn{3}{|l|}{ Lifestyle risk factors, $\%$} \\
\hline Current Smoking & 14.2 & 12.5 \\
\hline \multicolumn{3}{|l|}{ Clinical risk factors, $\%$} \\
\hline Diabetes mellitus & 26.0 & 27.1 \\
\hline Angina pectoris & 1.7 & 2.2 \\
\hline Acute myocardial infarction & 4.2 & 5.8 \\
\hline Renal failure & 2.0 & 0.6 \\
\hline Hypercholesterolaemia & 16.1 & 12.2 \\
\hline Previously known hypertension & 81.4 & 83.2 \\
\hline Mean weight in $\mathrm{Kg}(\mathrm{SD})$ & $67.1(11.96)$ & $68.4(13.4)$ \\
\hline Body mass index $\mathrm{Kg} / \mathrm{m}^{2}(\mathrm{SD})$ & $28.6(4.83)$ & $28.7(5.21)$ \\
\hline Sodium excretion in mmol/lt (SD) & $95.2(47.1)$ & $94.9(48.81)$ \\
\hline Not regular walking, \% & 39.0 & 39.8 \\
\hline Not brisk walking, $\%$ & 78.3 & 72.9 \\
\hline \multicolumn{3}{|c|}{ Mean blood pressure in mmHg (SD) } \\
\hline Systolic 1 & $161.9(18.4)$ & $162.1(18.4)$ \\
\hline Diastolic & $90.8(9.4)$ & $90.9(10.4)$ \\
\hline \multicolumn{3}{|l|}{ Blood pressure measurements, $\%$} \\
\hline Diastolic $\geq 90 \mathrm{~mm} \mathrm{Hg}$ & 39.0 & 39.3 \\
\hline Systolic $\geq 160 \mathrm{~mm} \mathrm{Hg}$ & 31.9 & 31.6 \\
\hline Diastolic $\geq 90$ and systolic $\geq 160 \mathrm{~mm} \mathrm{H}$ & 29.1 & 29.1 \\
\hline *American dollars & & \\
\hline
\end{tabular}

\section{Results}

At the end of the intervention period the difference in the mean change was a fall of $3.31 \mathrm{~mm} \mathrm{Hg}(95 \% \mathrm{CI}$ $6.32,0.29, p=0.03$ ) in systolic blood pressure and a fall of $3.67 \mathrm{~mm} \mathrm{Hg}(95 \%$ CI 5.22, $2.12 p<0.001)$ in diastolic blood pressure comparing the intervention group with the control group. In the intervention group, $12.9 \%$ of participants reported an increase in brisk walking, compared with $5.2 \%$ in the control group $(p=0.0004)$, and the proportion of people not anti-hypertensive medication decreased from $28.4 \%$ to $15.9 \%$, compared to a decrease from $32.2 \%$ to $26.9 \%$ in the control group $(p=0.001)$.

\section{Costs}

Cost items related to the training course are described in Table II. Table III presents the costs of equipment. Indirect costs such as patient or family time were not included because when the nurses asked, none of the participants reported a cost value of the time spent during the visits. The total cost of the transport was $\$ 7207.60$ pesos (US\$787.71), the average transport cost per visit was $\$ 2.70$ pesos (CI 95\% 2.42, 2.95 pesos). The average time per consultation was 43.58 minutes (CI 95\% 41.16, 45.89 min.). The total number of visits to the participants was 2944 (mean for a participant 8.53 , std. dev. $=2.10$ ). The total cost of the intervention nurses was 59096.82 pesos (US\$6,180.99). The total cost of the intervention was then calculated as follows:

Cost $=$ [number of consultations per patient average cost of a consultation (nurse time consultation+time travelling)+cost travelling] + other costs (equipment, office space, training, supplies) $=101901.66$ pesos (US\$11,136.79).

The average intervention cost per patient was 34.61 pesos (US\$3.78), $(p=0.000, \mathrm{CI} 95 \% 34.44,35.46)$. This cost was not significantly different $(p=0.61)$ in men and women (the cost for one woman was 35.05 pesos (US\$3.83) and for one man 34.78 pesos (US\$3.80).

The total number of clinic visits to the family physicians by the participants was also calculated. There were 1395 clinic visits in two hundred and sixty five participants (mean $=5.26$, std. dev. $=2.57$ ) in the intervention group and 1,392 visits in 259 participants (mean=5.37, std. dev.=1.85) in the control group. The difference between the groups was not significant $(p=0.22)$.

\section{Effects and cost/effectiveness ratios}

The differences in the mean change of systolic and diastolic blood pressure were used as the effectiveness measurements. The cost-effectiveness of the intervention was 10.46 pesos (US\$1.14) per millimetre reduction in systolic blood pressure or 9.43 pesos (US\$1.03) per millimetre reduction in diastolic blood pressure. Confidence intervals for the cost-effectiveness ratios 
Table II

\section{Cost of training. Mexican Institute of Social Security} (Instituto Mexicano del Seguro Social), 1998

\begin{tabular}{|c|c|c|c|c|c|c|}
\hline \multicolumn{7}{|c|}{ Recruitment and training of nurses } \\
\hline & Per month & Per year & Per hour & Time & Cost in pesos & Cost in* dollars \\
\hline \multicolumn{7}{|l|}{ Value time of trainer team: } \\
\hline Cardiologist & 8620.82 & 122258.96 & 78.37 & $3 \mathrm{hrs}$ & 235.11 & 25.70 \\
\hline Geriatrician & 8620.82 & 122258.96 & 78.37 & $4 \mathrm{hrs}$ & 313.48 & 34.26 \\
\hline Physical therapist & 8620.82 & 122258.96 & 78.37 & $3 \mathrm{hrs}$ & 235.11 & 25.70 \\
\hline Psychiatrist & 8620.82 & 122258.96 & 78.37 & $3 \mathrm{hrs}$ & 235.11 & 25.70 \\
\hline Supervisor & 3150.00 & 48609.04 & 25.32 & $80 \mathrm{hrs}$ & 2025.60 & 221.38 \\
\hline Researcher & 8620.82 & 122258.96 & 78.37 & $80 \mathrm{hrs}$ & 6269.60 & 685.20 \\
\hline Clinic space for course & & & & Two weeks & 11500.00 & 1256.83 \\
\hline Value time of nine nurses during the course & 2800.00 & & & Two weeks & 12600.00 & 1377.05 \\
\hline Partial total: training and clinic space & & & & & 33414.01 & 3651.82 \\
\hline
\end{tabular}

Table III Cost of Equipment. Mexican Institute
of Social Security (Instituto Mexicano
del Seguro Social), 1998

\begin{tabular}{|c|c|c|c|}
\hline \multirow[b]{2}{*}{ Equipment } & \multirow{2}{*}{$\begin{array}{l}\text { Cost per } \\
\text { unit pesos }\end{array}$} & \multicolumn{2}{|c|}{ Total costs } \\
\hline & & Pesos & Dollars \\
\hline Sphygmomanometers (nine)* & 255.96 & 2303.64 & 251.76 \\
\hline Stethoscope (nine) & 55.00 & 495.00 & 54.10 \\
\hline Uniforms for nine nurses & 150.00 & 1350.00 & 147.54 \\
\hline Total cost of supplies and stationery & & & \\
\hline (sheets, photocopies, pencils, erasers) & 5242.19 & 5242.19 & 572.92 \\
\hline Partial total: equipment & & 9390.83 & 1032.32 \\
\hline
\end{tabular}

are presented in Table IV. The cost of the control group is zero because a) the intervention is considered to be an incremental cost and b) the cost of family physician visits was not included as there was no significant difference between the trial arms. Variances and standard deviations of the effects $\left(\mathrm{S}_{\mathrm{ET}}^{2}, \mathrm{~S}^{2} \mathrm{EC}^{\prime}\right.$ and $\left.\mathrm{S}_{\mathrm{ET}}\right)$ assumed the values of change in systolic and diastolic blood pressure. The intervention cost per patient $\left(\mathrm{C}_{\mathrm{T}}\right)$ was 34.61 pesos $\left(\mathrm{S}_{\mathrm{CT}}=4.86, \mathrm{~S}_{\mathrm{CT}}^{2}=23.68\right.$ pesos). Symbol $\mathrm{r}_{\mathrm{T}}$ refers to the sample correlation coefficient of the cost an effect in the intervention group (Systolic $r_{T}=0.028$ and diastolic $\left.\mathrm{r}_{\mathrm{T}}=0.003\right)$. Table 4 includes values of the three coefficients of variation $\left(C_{d_{d}}, C_{n n}\right.$ and $\left.C_{n d}\right)$ and the resulting confidence intervals for systolic and diastolic cost-effectiveness ratios.

\begin{tabular}{|c|c|c|}
\hline & & \\
\hline $\begin{array}{r}\text { Tabl } \\
\text { Coefficients of Varia } \\
\text { Intervals for Cost E } \\
\text { Mexican Institute OF So } \\
\text { MeXicano Del Seg }\end{array}$ & $\begin{array}{l}\text { IV } \\
\text { TION AND C } \\
\text { FFECTIVENES } \\
\text { CIAL SECURI } \\
\text { JRO SOCIAL) }\end{array}$ & $\begin{array}{l}\text { FIDENCE } \\
\text { RATIOS. } \\
\text { (INSTITUTO } \\
\text { } 998\end{array}$ \\
\hline & $\begin{array}{l}\text { Systolic blood } \\
\text { pressure }\end{array}$ & $\begin{array}{l}\text { Diastolic blood } \\
\text { pressure }\end{array}$ \\
\hline $\begin{array}{l}\text { Coefficient of variation of } \\
\text { numerator of } R^{\wedge}\left(C_{n n}\right)\end{array}$ & 0.0000573 & 0.0000573 \\
\hline $\begin{array}{l}\text { Coefficient of variation of } \\
\text { denominator of } R^{\wedge}\left(C_{d d}\right)\end{array}$ & 0.22 & 0.0410 \\
\hline $\begin{array}{l}\text { Coefficient of variation of } \\
\text { denominator/numerator of } R^{\wedge}\left(C_{n d}\right)\end{array}$ & 0.0000688 & 0.00000315 \\
\hline $\begin{array}{l}\text { Cost effectiveness ratio }\left(\mathrm{R}^{\wedge}\right) \\
\text { Pesos } \\
\text { US\$ }\end{array}$ & $\begin{array}{c}10.46 \\
1.14\end{array}$ & $\begin{array}{l}9.43 \\
1.03\end{array}$ \\
\hline $\begin{array}{l}\text { 95\% Confidence Interval } \\
\text { Pesos } \\
\text { US\$ }\end{array}$ & $\begin{array}{cc}129.31 & 5.51 \\
14.13 & 0.60\end{array}$ & $\begin{array}{ll}19.90 & 2.49 \\
2.17 & 0.27\end{array}$ \\
\hline
\end{tabular}

\section{Discussion}

Much research has been published in the area of effective antihypertensive therapy, patient management guidelines and life-style management, but optimal methods for the delivery of care have not been fully explored. With this perspective, the aim of this study was to measure the incremental costs and effects of home visits by a nurse to elderly people with hypertension in Mexico. 
The cost effectiveness of the intervention was 10.5 pesos (US\$1.1) per mm Hg reduction of systolic blood pressure and 9.4 pesos (US\$1.0) per mm Hg reduction of diastolic blood pressure. This seems on face value to be a cost-effective intervention. However, it is not possible to draw a firm conclusion because it is not possible to make comparisons with alternative health care interventions based in Mexico which used other measures of effectiveness. The tool of economic analysis has emerged only recently in Mexico and little information exists. We cannot determine, therefore, if nurse visits to the elderly is the most cost-effective alternative. However, the estimated cost per millimetre of mercury reduction in blood pressure suggests that this intervention will prove to be highly cost effective.

This study is based on an outcome of reduction in blood pressure, which is an immediate outcome. We do not have any information on the sustainability of the intervention, and the future benefits of the intervention in terms of mortality, morbidity or quality of life are unknown. Because the target group is elderly, it is not possible to model the effects of blood pressure reduction on mortality. Models for estimating life years gained after blood pressure reduction have been criticised for discriminating against older people, due to a shorter life expectancy of older people. ${ }^{12}$ Unfortunately, models have not been developed for people over 70 years old. As a consequence the utilization of modelling would underestimate the cost-effectiveness ratio.

The number of clinic consultations with the family physician was not statistically different between the groups. If future benefits are achieved in the intervention group, it is possible that there will be a decrease in utilisation rates for second and third levels of care and a decrease in the disability rates. On the other hand the intervention lead to increased prescribing of antihypertensive drugs and this has not been considered in our estimate of cost. Indirect costs were not included in the analysis because none of the participants reported any. One of the reasons for this was that the nurse always arranged the appointment with the participant and he/she could choose a time that was convenient. By arranging home visits at times that are convenient to the participant, indirect costs can be greatly reduced. Many health policy makers argue that health promotion practices and preventive care are a way of reducing health care costs. However, the idea that health promotion and preventive strategies are cheap and will save money, is too simplistic. Indeed, in the case of the elderly population, health promotion activities could add to the costs of the medical expend- iture but they will also represent future benefits in terms of a better quality of life, a decrease in disability and the possibility of a successful ageing. ${ }^{13}$

Recognition that health can be promoted for the elderly to improve the quality of life has increased in the last few years ${ }^{14}$ but the process by which research data are incorporated into a clinical setting is complicated. Economic features, organisational aspects, uncertainty about the usefulness of the results, technical barriers are some of the obstacles in the process of linking research into policy. ${ }^{15}$ Ensuring that the health promotion strategy that we tested is effective is an important step, but not enough. As is true everywhere in the world, institutional resources in Mexico will remain limited and interventions for the elderly must be shown to be cost-effective if they are to compete against the resource demands of other worthwhile interventions. The intervention evaluated in this study has been shown to be effective at very small cost, but whether this represents good value compared with other health interventions remains to be determined. Moreover, there is, as yet, no relevant data on the effectiveness or cost of other possible interventions aimed at blood pressure reduction in an elderly Mexican population, such as self help groups and future research has to be done in this area.

This study is important because introduces the tool of the economic analysis in the arena of health promotion for elderly people. In México, health system has to be reorganized in order to response to the growing needs of this group of age and research is a key element in this process. Hypertension and their consequences (stroke and coronary heart disease) is the most important cause of mortality and disability among the elderly. Cost-effective strategies that improves health and promotes healthy aging are crucial if we want to diminish an increasing utilization of third level hospitals and the subsequent costs.

\section{References}

1. Secretaría de Salud. Boletín de Información Estadística, Recursos y Servicios. México, D.F.: SSA;1997.

2. Secretaría de Salud. Encuesta Nacional de Enfermedades Crónicas. México, D.F.: D irección General de Epidemiología, 1996.

3. García-Peña C, Thorogood M,Armstrong B, Reyes S, Muñoz O. Pragmatic Randomised Trial of Home Visits by a Nurse to Elderly People with Hypertension in Mexico. Int J Epidemiol 2001.

4. García-Peña C, Thorogood M, Reyes S, Salmerón-Castro J, D urán C. The prevalence and Treatment of Hypertension in Elderly Population. Salud Publica Mex 2001;43:415-420.

5. Kaplan N. Cost Considerations in the drug treatment of the Mexican Institute of Social Security hypertension. Is older better? Pharmacoeconomics 1996;9:283-285. 
6. Johannesson M. The cost effectiveness of hypertension treatment in Sweden. Pharmacoeconomics 1995;7:242-250.

7. Edelson D, W einstein M, Tosteson A, W illims L, Lee T, Goldman L. Longterm cost-effectiveness of various initial monotherapies for mild to moderate hypertension. JAMA 1990;263:407-413.

8. Mancia G, Giannattasio $C$. Benefit and costs of anti-hypertensive treatment. Eur Heart J 1995;17 (Suppl A):25-28.

9.W onderling D, MCD Ermott Ch,Buxton M, KinmonthA, Pyke S,Thompson S. Costs and cost effectiveness of cardiovascular screening and intervention: the British Family Heart Study. BMJ 1996;312:1269-1273.

10. W onderling D, Langham S, Buxton M, N ormand Ch, McD ermott $\mathrm{CH}$. W hat can be concluded from the 0 xcheck and British Family Heart Studies: commentary on cost effectiveness analyses. BMJ 1996;312:1274-1278.

11. Chaundhary M, Steams S. Estimating confidence intervals for costeffectivness ratios: An example from a randomized trial. Stat Med 1996;15:1447-1458.
12. Johannesson $N$, Johansson $P$. Is the evaluation of a $Q A L Y$ gained independent of age? Some empirical evidence. J Health Economics 1997;16:589-599.

13. Kennie D. Preventive Care for Elderly People. Londres: Cambridge University Press, 1993:310.

14. KalacheA. Health promotion. En:Ebrahim S, KalacheA, ed. Epidemiology in old age. Londres: Latimer Trend, 1996:156.

15. Lewando-Hundt G, Al Zaroo S (2000). Evaluation the dissemination of health promotion research. En:Thorogood M, C oombesY. Evaluation Health Promotion. Practice and Methods. 0 xford (UK): 0 xford U niversity Press, 2000:151. 